\title{
Stable isotope analysis of baleen reveals resource partitioning among sympatric rorquals and population structure in fin whales
}

\author{
Conor Ryan ${ }^{1}$, Brendan McHugh², Clive N. Trueman ${ }^{3}$, Richard Sabin ${ }^{4}$, Robert Deaville ${ }^{5}$, Chris \\ Harrod $^{6,7}$, Simon D. Berrow ${ }^{1,8}$, lan O'Connor ${ }^{1}$ \\ ${ }^{1}$ Galway-Mayo Institute of Technology, Dublin Road, Galway, Ireland \\ ${ }^{2}$ Marine Institute, Rinville, Oranmore, County Galway, Ireland \\ ${ }^{3}$ Ocean and Earth Science, University of Southampton, National Oceanography Centre, European Way, \\ Southampton SO14 3ZH, UK \\ ${ }^{4}$ Vertebrates Group, Department of Zoology, Natural History Museum, Cromwell Road, London SW7 5BD, UK \\ ${ }^{5}$ UK Cetacean Strandings Investigation Programme, Institute of Zoology, Zoological Society of London, Regent's Park, London NW1 \\ 4RY, UK \\ ${ }^{6}$ School of Biological Sciences, Medical Biology Centre, 97 Lisburn Road, Queen's University Belfast, Belfast BT9 7BL, UK \\ ${ }^{7}$ Instituto de Investigaciones Oceanológicas, Universidad de Antofagasta, Avenida Angamos 601, Antofagasta, Chile \\ ${ }^{8}$ Irish Whale and Dolphin Group, Merchant's Quay, Kilrush, County Clare, Ireland
}

\begin{abstract}
Stable isotope analysis is a useful tool for investigating diet, migrations and niche in ecological communities by tracing energy through food-webs. In this study, the stable isotopic composition of carbon and nitrogen in keratin was measured at growth increments of baleen plates from 3 sympatric species of rorquals (Balaenoptera acutrostrata, B. physalus and Megaptera novaeangliae), which died between 1985 and 2010 in Irish and contiguous waters. Bivariate ellipses were used to plot isotopic niches and standard ellipse area parameters were estimated via Bayesian inference using the SIBER routine in the SIAR package in R. Evidence of resource partitioning was thus found among fin, humpback and minke whales using isotopic niches. Highest $\delta^{15} \mathrm{~N}$ values were found in minke whales followed by humpback, and fin whales. Comparison between Northeast Atlantic (Irish/UK and Biscayan) and Mediterranean fin whale isotopic niches support the current International Whaling Commission stock assessment of an isolated Mediterranean population. Significantly larger niche area and higher overall $\delta^{15} \mathrm{~N}$ and $\delta{ }^{13} \mathrm{C}$ values found in fin whales from Irish/UK waters compared to those sampled in adjacent regions (Bay of Biscay and Mediterranean) suggest inshore foraging that may be unique to fin whales in Ireland and the UK. Isotopic profiles support spatial overlap but different foraging strategies between fin whales sampled in Ireland/UK and the Bay of Biscay. Stable isotope analysis of baleen could pro- vide an additional means for identifying ecological units, thus supporting more effective management for the conservation of baleen whales.
\end{abstract}

KEYWORDS: Diet, Isotopic niche, Foraging, Stock discrimination, Northeast Atlantic, Bayesiananalysis

\section{INTRODUCTION}

Following 2 centuries of commercial whaling, the current ecological assemblage and population sizes of rorquals (Family Balaenopteridae) are believed to be very different to those of pre-whaling times (Roman \& Palumbi 2003, Baker \& Clapham 2004). While we know little of their ecosystem role, the near extirpation of some species of baleen whales may have been associated with subsequent trophic cascades 
(Springer et al. 2003, Ballance et al. 2006). Poorly managed fisheries may exert top-down control on marine food webs, assuming the functional role of apex predators such as cetaceans, hence replacing them (Trites et al. 2006). Policies for sustainable management of marine resources are attempting to move from single species based approaches to include ecosystem-scale effects, but designing effective ecosystem-based management requires knowledge of species interactions within a spatio-temporal context (Pauly et al. 2002, Gerber et al. 2009). These data are often missing, particularly for highly migratory, high trophic level predators. Basic biological information on foraging strategies, relative trophic positions and resource partitioning is also needed for effective species-based management and maintenance of cetacean populations. In this study, the foraging ecology of 3 species of rorqual - fin whales Balaenoptera physalus, humpback whales Megaptera novaeangliae and minke whales $B$. acutrostratus, which occur sympatrically in the North- east Atlantic (NEA) - were investigated using stable isotope analysis of baleen plates.

In the North Atlantic fin, minke and humpback whales are considered to be generalist predators, consuming pelagic schooling fishes, primarily capelin Mallotus villosus and herring Clupea harengus (Piatt \& Methven 1992, Lindstrøm et al. 2002, Laidre et al. 2010, Skern-Mauritzen et al. 2011) and zoo- plankton such as krill (Euphausiacea) and amphipods (Hobson et al. 2002). Fin whales in the NEA and Mediterranean Sea are known to feed chiefly on northern krill Meganyctiphanes norvegica and other zooplankton (Relini et al. 1992, Aguilar 2008, Skern- Mauritzen et al. 2011, Visser et al. 2011). However in Ireland, they occur in inshore waters for up to 10 mo of the year (Whooley et al. 2011), where they associate strongly with an inshore movement of spawning herring (Fairley 1981). Gut content-analysis of fin whales landed at a whaling station in Ireland in 1912 indicated that fin whales were feeding on both clupeids ('herrings') and northern krill (Fairley 1981). Two studies on the diet of minke whales in Scotland yielded consistent findings that minke whales had a piscivorous diet (Macleod et al. 2004, Pierce et al. 2004).

Rorquals are difficult to study as they can be elusive and often occur offshore, ranging over large geographical areas. Rapid onset of autolysis in stranded specimens due to their large body sizes usually renders gut content analysis impractical. A moratorium on whaling, along with conservation and ethical issues, preclude lethal sampling for research.
Given these challenges, stable isotope analysis (SIA) is a tool that is being used with increasing frequency in marine mammal research to address gaps in our knowledge (Newsome et al. 2010, Ramos \& González- Solís 2012, Ryan et al. 2012). While conventional diet analyses such as fecal or stomach content analysis may offer high taxonomic resolution, they provide information over a short timescale and are subject to additional sources of uncertainty and bias (Layman et al. 2007, Pierce et al. 2007). Stable isotope values of tissues reflect those of the environment and prey from which the tissues were synthesised (DeNiro \& Epstein 1978). SIA can provide information on migratory movements and foraging habits of animals pro- vided that they feed along a known isotopic gradient and that trophic enrichment factors are reliably constrained (e.g. Harrod et al. 2005, Graham et al. 2010, MacKenzie et al. 2011, Trueman et al. 2012a,b). The technique can provide quantitative data to investigate inter alia resource partitioning and other complex processes that govern structure in ecological communities(Jacksonetal.2012).

In the marine environment baseline $\delta^{13} \mathrm{C}$ and $\delta^{15} \mathrm{~N}$ values, i.e. those of particulate organic matter (POM), vary with both latitude and proximity to shore. These broad geographic patterns are driven by variation in the degree of isotopic fractionation during photosynthesis, and the isotopic composition of the inorganic carbon utilised by phytoplankton (Goericke \& Fry 1994, Hofmann et al. 2000, Fry 2006, Tagliabue \& Bopp 2008, Graham et al. 2010). Because of its sensitivity to plankton growth rates and seawater carbonate chemistry, the isotopic composition of POM is subject to dynamic climatic and oceanographic forcings at all spatiotemporal scales (Newsome et al. 2007a, MacKenzie et al. 2011, Trueman et al. 2012a). Despite predictable gradients in stable carbon isotope ratios at an ocean-basin scale, their usage in assigning geographic location to marine animals is confounded by additional temporal and small-scale spatial variations (due to, e.g. upwelling), which may be difficult to predict (Rau et al. 1992, Hofmann et al. 2000, MacKenzie et al. 2011).

Spatial heterogeneity is also found in the nitrogen stable isotope compositions of marine primary producers due to differential fractionation (Montoya 2007) and differences in the isotopic composition of nitrogen assimilated during cell growth. One study in the inshore seas around the UK showed that $77 \%$ of variability in $\delta^{15} \mathrm{~N}$ values of whiting Merlangius merlangus was attributed to differences at the base of the food chain rather than trophic level (Jennings \& Warr 2003). Baseline phytoplankton $\delta^{15} \mathrm{~N}$ values are dictated by the availability 
and types of nutrients (ammonium, nitrate or $\mathrm{N}_{2}$ ) from which they are sourced. Broad latitudinal regions are characterised by specific mechanisms of nitrate utilization, for example $\mathrm{N}_{2}$ fixation in sub-tropical gyres and nitrate assimilation in vertically-mixed mid to high latitude regions. Considering that nitrogen availability to phytoplankton and its isotopic composition dictates baseline $\delta^{15} \mathrm{~N}$ values, inputs of terrestrial nitrogen can manifest as a gradient of isotopic enrichment towards the shore in marine food webs (Jennings \& Warr 2003).

The ecological niche concept formally defined by Hutchinson (1957) has become fundamental in com- munity ecology theory. Defined as an ' $n$-dimensional hypervolume', a niche is a space that encloses $n$ limiting dimensions of the environment in which an organism can occur (Hutchinson 1957). The range of stable isotope compositions measured in individuals may be used to quantify trophic niche dimensions, contributing to a resurgence of interest in the niche concept and giving rise to the 'isotopic niche' or ' $\delta$ - space' (Newsome et al. 2007b). Theoretically, the isotopic niche approximates the trophic niche (Bearhop et al. 2004, Layman et al. 2007) such that isotopic niche space (the range of isotopic values in \%o) and niche area (the area occupied in bi-plot space in $\%^{2}$ ) provide insight into resource partitioning and specialization respectively. Where baseline isotope values are unknown, the isotopic niche approximates trophic niche with an added component of variation associated with environmental variability in time and space. In this context, differences in isotopic niche space between 2 samples may indicate either differences in the diversity of prey organisms or differences in the area (and/or time) foraged.

Incremental sampling of accretionary tissues can provide a longitudinal record of isotopic proxies for both diet and habitat use (Mendes et al. 2007, New- some et al. 2009). Synthesized from metabolites of the bloodstream and composed almost exclusively of keratin, baleen is an accretionary tissue suitable for investigating long-term foraging via stable isotope analysis (Schell et al. 1989a). In one study where minke whale baleen was sampled along the growth axis, isotopic values from the most recent $10 \mathrm{~mm}$ segment of baleen were found to reach equilibrium with those of muscle (Hobson et al. 2004). Thus baleen isotope values exhibit similar carbon and nitrogen assimilation rates to muscle (several months, al- though this is not established experimentally) representing metabolic pathways of proteins rather than mobilized lipid stores (Hobson et al. 2004).
The International Whaling Commission (IWC) aims to manage baleen whale populations based on identification of geographically explicit and biologically relevant units (Donovan 1991). However management units are difficult to define. In the management of fin whales in particular, 'stock' discrimination remains poorly resolved in the North Atlantic (IWC 2007). Here we compare isotopic niches estimated via a Bayesian inference framework to infer population connectivity in fin whales sampled in 3 adjacent geographic locations: Ireland/UK, Bay of Biscay and the Mediterranean Sea.

\section{MATERIALS AND METHODS}

Baleen plates from adult fin $(n=7)$, minke $(n=3)$ and humpback $(n=3)$ whales found stranded around Ireland and the UK were sampled from collections or taken directly from carcases in the case of recent samples (Fig.1, see Table 1). Samples were also taken from fin whales $(n=3)$ landed at Caneliñas whaling station in northern Spain before the international moratorium on whaling. These fin whales were killed in the Bay of Biscay near Cape Finisterre at unknown dates between July and August 1985. While length of these animals was unknown, they were assumed to be $>17 \mathrm{~m}$ in accordance with catch regulations

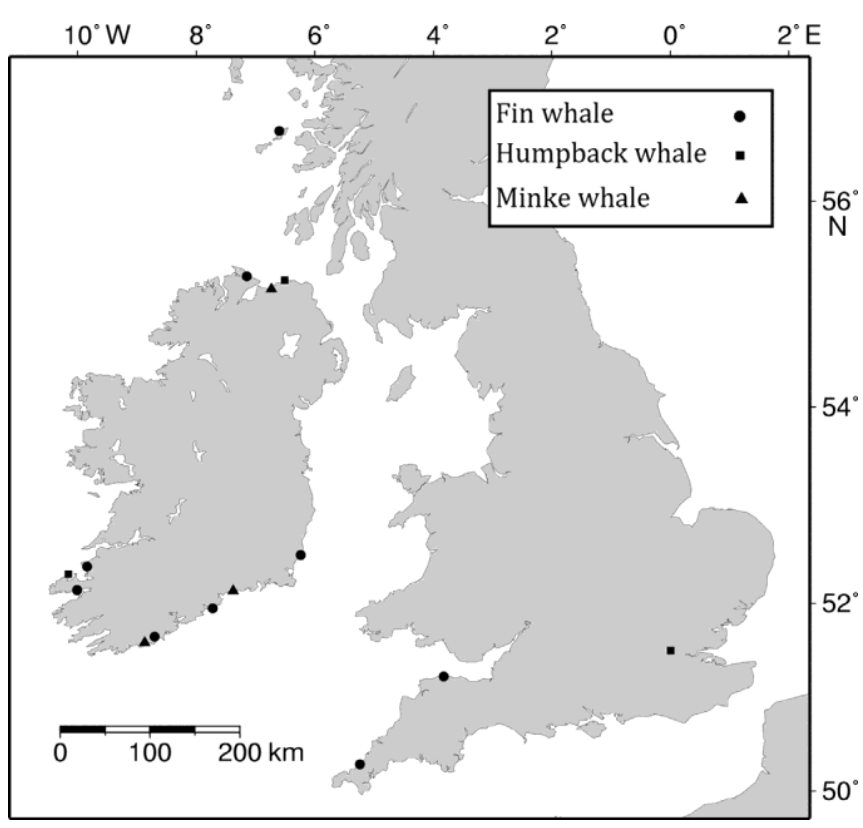

Fig. 1. Whale strandings from which baleen plates were sampled (see Table 1). Bay of Biscay sampling locations were only approximate and therefore not presented here 
at that time. In order to ensure that our results were directly comparable with those of a study on Mediterranean fin whales (Bentaleb et al. 2011), a consistent sample preparation was adopted. Baleen plates were air-dried and stored at room temperature, scoured using steel wool and cleaned with 1:1 methanolchloroform solution to remove any extraneous material such as adhering lipids. As baleen is composed almost exclusively of protein (keratin), tissue treatment such as lipid or carbon- ate extraction is not necessary. Incremental sampling was carried out longitudinally (i.e. along the growth axis) on each plate at locations measured using demarcated adhesive tape (due to curvature of some plates when dried), from the gingival end to the distal tip. Along the transverse axis, tissue synthesis is uniform (Schell et al. 1989b). Samples were taken within 0 to $20 \mathrm{~mm}$ of the non-frilled (outer) edge, where the growth axis is longest (Bentaleb et al. 2011), with increments of $50 \mathrm{~mm}$ (fin), 20 $\mathrm{mm}$ (humpback) and $10 \mathrm{~mm}$ (minke whale). Samples were simultaneously removed and homogenised using a rotary engraving tool with a stain- less steel tip (1 $\mathrm{mm}$ diameter) that was cleaned between samples using deionised water. Approximately $1.5( \pm 0.5) \mathrm{mg}$ of tissue were weighed into tin cups and analysed for carbon and nitrogen isotope ratios by continuous flow elemental analysis isotope ratio mass spectrometry (CF-EA-IRMS). Measurements were carried out using a EuroVector EA 3000 elemental analyzer (EA) interfaced with a Europa Scientific 20-20 isotope ratio mass spectrometer (IRMS) at the University of Southampton. Routine analysis of in-house laboratory standards (Acros L-glutamic acid) was used to estimate instrument accuracy and precision. Carbon and nitro- gen isotope ratios were determined against a reference standard, glutamic acid, which itself was referenced with IAEA Vienna Pee Dee Belemnite and atmospheric air.

The elemental carbon to nitrogen ratio (C:N) was used as quality assurance to assess stable isotope values before subsequent analyses. A single fin whale sample with a C:N ratio of 4.2 was outside of the theoretical value of $3.4 \pm 0.5$ for pure keratin and therefore omitted from all analyses (O'Connell

\& Hedges 1999, Bentaleb et al. 2011). All plates analysed comprised $>1 \mathrm{yr}$ growth according to known or estimated baleen growth rates for the species concerned. A continuous growth rate of baleen was assumed to be $20 \mathrm{~cm} \mathrm{yr}^{-1}$ for fin (Bentaleb et al. 2011) and $12 \mathrm{~cm} \mathrm{yr}^{-1}$ for minke (Mitani et al. 2006) whales. The growth rate of humpback baleen is not known; however, based on proportionate body size, it is assumed to be intermediate between fin and minke whales and thus $15 \mathrm{~cm} \mathrm{yr}^{-1}$ was assumed. Grey whales are of similar body length and weight and are known to have a baleen growth rate of between 10 and $20 \mathrm{~cm} \mathrm{yr}^{-1}$ (Sumich 2001). Growth rates were used to ensure that samples comprised at least $1 \mathrm{yr}$ of growth for each individual sampled. For some plates, the gingival end was missing, thereby precluding the construction of a time-series from a known point in time.

The use of Euclidean methods, such as convex hulls to define the isotopic niche space of a species in a community (Layman et al. 2007), is subject to sampling biases and sensitive to sample size (Jackson et al. 2011). Standard area ellipses estimated by Bayesian inference can incorporate uncertainties such as sampling biases and small sample sizes into niche metrics (Jackson et al. 2011). Here, resource partitioning is investigated using the Stable Isotope Bayesian Ellipses in $\mathrm{R}$ (SIBER) routine in SIAR, a package in the $\mathrm{R}$ programming environment, to examine variation in $\delta^{13} \mathrm{C}$ and $\delta^{15} \mathrm{~N}$ values and estimate isotopic niche space (Jackson et al. 2011, R Development Core Team 2011). This approach is similar to bootstrapping in that it iteratively assigns measures of uncertainty, in this case based on Markov-Chain Monte Carlo (MCMC) simulation to constructparameters of ellipses.

Bivariate ellipses and convex hulls were used to delineate isotopic niche space $\left(\delta^{15} \mathrm{~N}-\delta^{13} \mathrm{C} 95 \%\right.$ confidence interval ellipses) and the total extent of isotopic niche respectively among species (Jackson et al. 2011). Bayesian standard ellipses $\left(S E A_{c}\right)$, corrected for small sample sizes by 2 standard deviations ( $n-1$ for each axis) were then plotted using the SIBER routine in the SIAR package in $R$ (version 2.14.1) (Jackson et al. 2011, R Development Core Team 2011). Niche area and overlap $\left(\%{ }^{2}\right)$ were estimated based on 100000 posterior draws of the SEAc parameters, which are comparable among and within ecological communities (Jackson et al. 2011). By including bivariate isotopic data for individual whales for increments representing $>1 \mathrm{yr}$ of baleen growth (see Table 1), isotopic variation in diet, space and time was incorporated into the posterior distribution. Niche space and area were thus comparable among the 3 species. Similarly, niche space and area were compared between fin whales in order to investigate for evidence of population structure between 3 sampling regions: Ireland/UK, Bay of Biscay (data from present study) and the Mediterranean (Bentaleb et al. 2011). 


\section{RESULTS}

In order to investigate resource partitioning (niche space) and resource specialization (niche area) among fin, humpback and minke whales from Irish and UK waters, baleen plates were sampled from collections for stable isotope analysis (Fig. 1, Table 1). Only specimens with data on stranding location, date, species and total body length were included (Table 1). From 3 separate runs, the minimum instrumental precision (SD) was $<0.2 \%$ for both $\delta^{15} \mathrm{~N}$ and $\delta^{13} \mathrm{C}$ values respectively for the CF-EA-IRMS. Baleen plates from fin $(n=10)$, minke $(n=3)$ and humpback ( $\mathrm{n}=3$ ) whales were sub-sampled. The mean C: $\mathrm{N}$ ratio (range) of baleen subsamples from fin $(n=65)$, humpback ( $n$ $=51$ ) and minke whale $(n=48)$ was 3.4 (3.2 to 3.7$), 3.5$ (3.3 to 3.7 ) and 3.4 (3.2 to 3.5 ) respectively.

\section{Isotopic niche space}

Distinct isotopic niche space was found between the 3 species: fin, humpback and minke whales (Fig. 2). The probabilities that different species occupied distinct niche spaces were estimated as the extent of overlap between ellipses. These probabilities were derived by Bayesian inference where the posterior probability of the model $M$, given the data $D$, i.e $\operatorname{Pr}(M \mid D)$, was based on $100000 \mathrm{MCMC}$ draws. The probability of isotopic niche overlap, estimated from posterior distributions, among these 3 species was very low $\operatorname{Pr}(M \mid D)<0.001)$. Significant isotopic niche partitioning was also demonstrated between Mediterranean fin whales and those from other sampling locations (Fig. 3). However, there was consider- able overlap in niche space between fin whales from the Bay of Biscay and Ireland/UK (98.7\%) indicating considerable shared isotopic niche space.

\section{Isotopic niche areas}

Isotopic niche areas $\left(\%^{2}\right)$ for fin, humpback and minke whales from Irish/UK waters, delineated by SEAc, which is adjusted for sample size, are presented in Fig. 2. Minke whales occupied the smallest isotopic niche area, consistent with high resource specialization, while fin and humpback whales exhibited larger isotopic niche areas (Fig. 2). Probabilities that niche areas differ in extent were derived by Bayesian inference, whereby $\operatorname{Pr}$ values imply support of the actual hypothesis presented and not the null hypothesis. The probability, for the posterior distribution (based on 100000 draws) of the parameters of model $M$ given the prior data $D$, that humpback whales occupy a greater isotopic niche area

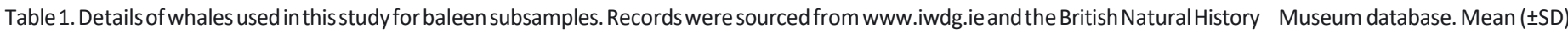
$\delta^{13} \mathrm{C}$ and $\delta^{15} \mathrm{~N}$ values from each baleen plate are presented

\begin{tabular}{|c|c|c|c|c|c|c|c|c|c|}
\hline Specimen & Date & Species & Location & $\begin{array}{c}\text { Body } \\
\text { length }(\mathrm{m})\end{array}$ & $\begin{array}{c}\text { Baleen } \\
\text { length }(\mathrm{mm})\end{array}$ & Sex & тм13 & тм15 & $\mathrm{n}$ \\
\hline \multicolumn{10}{|c|}{ Brandon Bay, Co. Kerry, Ireland } \\
\hline IRMn04001 & 13-Sep-04 & Humpback & Giant's Causeway, Co. Antrim, UK & 8 & 30 & M & $-19.2(0.15)$ & $13.4(0.41)$ & 15 \\
\hline GBMn09001 & 12-Sep-09 & Humpback & QE2 Bridge, London, UK & 9.5 & 42 & $\mathrm{M}$ & $-17.6(0.76)$ & $12.3(1.72)$ & 21 \\
\hline IRBa93001 & 11-Jul-93 & Minke & Portstewart, Co. Derry, UK & 9.4 & 19 & $\mathrm{~F}$ & $-15.9(0.42)$ & $13.5(0.44)$ & 19 \\
\hline IRBa01002 & 04-Dec-01 & Minke & Ballydowane, Co.Waterford, Ireland & 7.84 & 14 & M & $-16.5(0.48)$ & $12.7(0.87)$ & 13 \\
\hline IRBa08001 & 20-Sep-08 & Minke & Duneen, Co. Cork, Ireland & 7.47 & 16 & M & $-16.8(0.28)$ & $13.9(0.38)$ & 16 \\
\hline \multicolumn{10}{|c|}{ Data in Figs. 2 \& 3} \\
\hline IRBp94001 & 01-Apr-94 & Fin & Ballyheigue, Co. Kerry, Ireland & 24 & 55 & $\mathrm{~F}$ & $-17.9(0.67)$ & $9.3(0.75)$ & 10 \\
\hline IRBp01001 & 05-Dec-01 & Fin & Whiting Bay, Co. Waterford, Ireland & 18.9 & 45 & M & $-16.7(0.53)$ & $12.2(0.97)$ & 8 \\
\hline GBBp04001 & 01-Feb-04 & Fin & Isle of Coll, Scotland, UK & 17.1 & 40 & $\mathrm{~F}$ & $-17.8(0.38)$ & $8.5(0.42)$ & 7 \\
\hline IRBp08012 & 11-Oct-08 & Fin & Inch, Co. Kerry, Ireland & 18.5 & 60 & $\mathrm{~F}$ & $-19(0.22)$ & $8.4(0.71)$ & 12 \\
\hline $\begin{array}{l}\text { IRBp09001 } \\
\text { IRBp09002 }\end{array}$ & $\begin{array}{l}\text { 15-Jan-09 } \\
\text { 01-Feb-09 }\end{array}$ & $\begin{array}{l}\text { Fin } \\
\mathrm{Fi}\end{array}$ & $\begin{array}{l}\text { Courtmacsherry, Co. Cork, Ireland } \\
\text { Ballyduboy, Co. Wexford, Ireland }\end{array}$ & $\begin{array}{c}19.7 \\
16\end{array}$ & $\begin{array}{l}70 \\
40\end{array}$ & $\begin{array}{c}\mathrm{F} \\
\mathrm{M}^{\mathrm{a}}\end{array}$ & $\begin{array}{l}-18.6(0.21) \\
-18.8(0.15)\end{array}$ & $\begin{array}{l}9.2(0.6) \\
9.8(0.29)\end{array}$ & $\begin{array}{c}13 \\
8\end{array}$ \\
\hline GBBp10001 & 23-Feb-10 & Fin & Porthtowan, Cornwall, UK & 16.9 & 40 & $\mathrm{~F}$ & $-17.8(0.52)$ & $11.6(0.99)$ & 7 \\
\hline \multicolumn{10}{|l|}{ Data in Fig. 3} \\
\hline SPBp85001 & 31-Jul-85 & Fin & 100 nm NW Cape Finnistere, Spain & $>17$ & 55 & - & $-17.9(0.29)$ & $9(0.41)$ & 12 \\
\hline SPBp85002 & 31-Jul-85 & Fin & 100 nm NW Cape Finnistere, Spain & $>17$ & 65 & - & $-19(0.35)$ & $10(0.47)$ & 13 \\
\hline SPBp85003 & 31-Jul-85 & Fin & 100 nm NW Cape Finnistere, Spain & $>17$ & 55 & - & $-18.1(0.3)$ & $9.8(0.48)$ & 11 \\
\hline
\end{tabular}



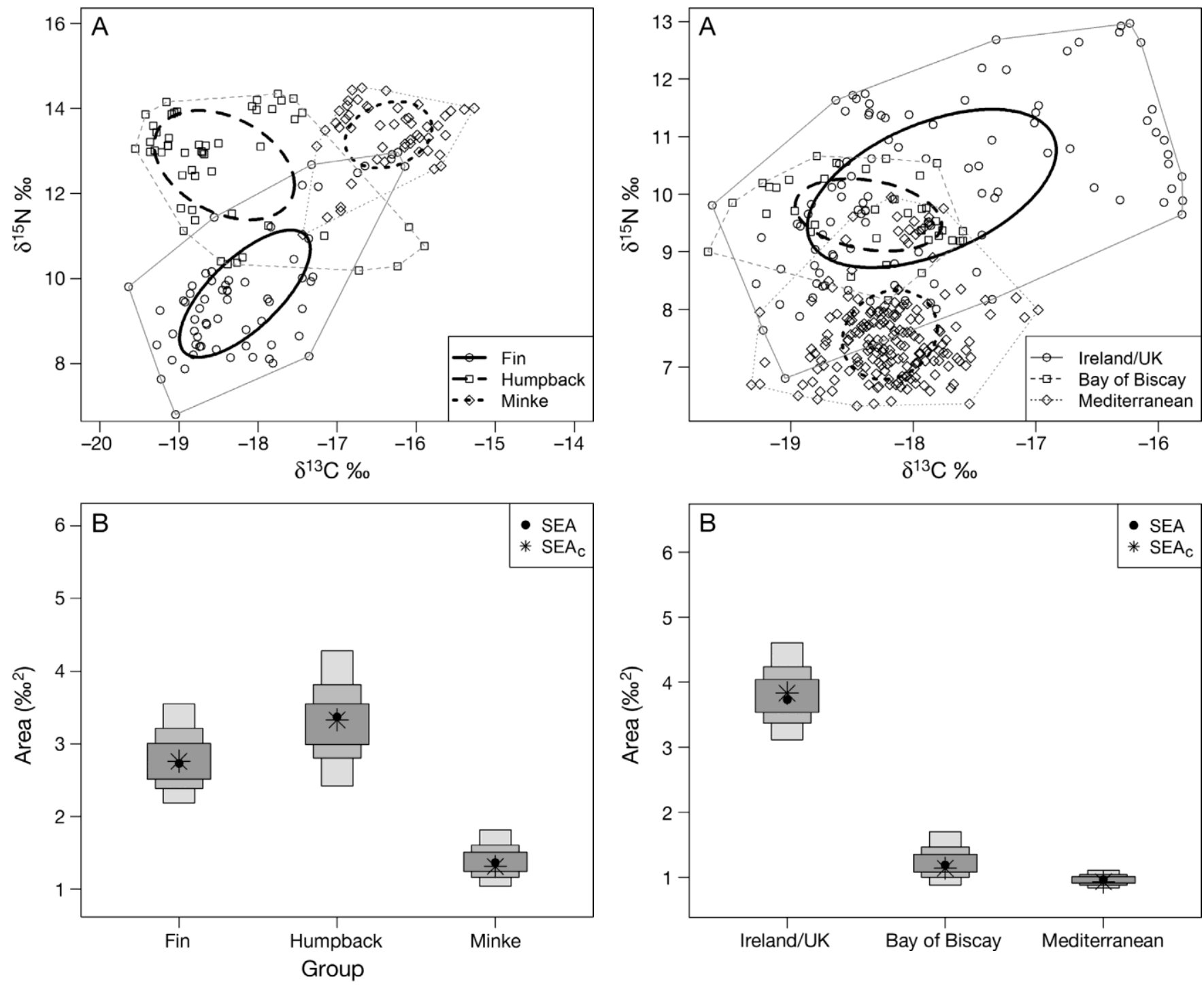

Fig. 2. (A) Variation in $\delta^{13} \mathrm{C}$ and $\delta^{15} \mathrm{~N}$ values for fin $(n=7)$, humpback (3) and minke (3) whales from Ireland/UK only. Thick black and thin grey lines: $95 \% \mathrm{Cl}$ bivariate ellipses and convex hulls respectively of $\delta^{13} \mathrm{C}$ and $\delta^{15} \mathrm{~N}$ values plot- ted according to species for adults only (see Table 1), demonstrating the significant isotopic niche partitioning among the 3 rorqual species. (B) Measures of uncertainty and central tendency (black symbols $=$ mode) of Bayesian standard ellipse areas (SEAc, corrected for small samples in a bivariate distribution for $2 \mathrm{df}$ ) based on 100000 posterior draws of parameters showing 95, 75 and $50 \%$ credibility intervals from light to dark grey respectively. See 'Results' section for probabilities of differences in area for species

than fin whales is $\operatorname{Pr}(M \mid D)=0.20$. Fin whales sampled in Ireland/UK exhibited a niche area significantly greater than those of both the Mediterranean and the Bay of Biscay $\operatorname{Pr}(M \mid D)<$ 99.999\%). Temporal differences in the samples may account for some of this difference, particularly between Bay of Biscay

Fig. 3. (A) $\delta^{13} \mathrm{C}$ and $\delta^{15} \mathrm{~N}$ values plotted according to sam- pling area. Black and grey lines: show significant isotopic niche partitioning between fin whales from the Mediterranean and other sampling regions (see Fig. 2 for details; Table 1) Fin whales from Bay of Biscay and Ireland/UK occupy com- mon isotopic niche areas. Note: data from a previously published study are included (e) (Bentaleb et al. 2011).

(B) Measures of uncertainty and central tendency of Bayesian standard ellipse areas (SEA $)$, see Fig, 2 for details. While fin whales from Ireland/UKsharethe sameisotopicnichespace as those from Bay of Biscay, the niche area of the former is significantly greater

( 4 yr) and other locations ( 18 and $30 \mathrm{yr}$ for Ireland/UK and the Mediterranean respectively). However, temporal changes in either $\delta^{13} \mathrm{C}$ or $\delta^{15} \mathrm{~N}$ values are unlikely to be of such a magnitude, that niche areas would increase greatly. The Seuss effect is the reduction in ${ }^{13} \mathrm{C}$ relative to ${ }^{12} \mathrm{C}$ due to anthropogenic burning of ${ }^{12} \mathrm{C}$ rich 
fossil fuels, which may account for some differences in $\delta^{13} \mathrm{C}$ when comparing samples taken over large timescales. Such changes are likely to be immaterial in the context of this study, e.g. $\sim 0.45 \%$ global aver- age over the $30 \mathrm{yr}$ sampling period in the case of fin whale samples (Sonnerup et al. 1999). While the isotopic niche space of Biscayan fin whales overlapped with that of Ireland/UK fin whales, the probability of the latter exhibiting a larger overall niche area was very high $\operatorname{Pr}(M \mid D)=$ 1). The probability that posterior $S E A_{C}$ of Mediterranean fin whales was less than that of Biscayan fin whales was also high $(\operatorname{Pr}(M \mid D)=0.92)$ indicating a very small isotopic niche for Mediterranean fin whales (Fig. 3).

\section{DISCUSSION}

Of the 6 rorqual species occurring sympatrically in the NEA, 3 were considered in this study. Knowledge on the diet of fin and humpback whales from recent times in the NEA is lacking (O'Brien et al. 2009, Wall et al. 2009, Whooley et al. 2011). However fin whales in both the Mediterranean Sea and the Bay of Biscay, and minke whales in Scotland are known to feed preferentially on northern krill and both lesser sand- eel Ammodytes marinus and herring respectively (Relini et al. 1992, Pierce et al. 2004, Aguilar 2008). A review of the literature providing evidence of potential resource overlap between fin, humpback and minke whales in the NEA prompted the use of stable isotope analysis to investigate resource partitioning using isotopic niches. Stable isotope analysis of baleen was used to elucidate long-term isotopic niche, which it has been argued is a function of both trophic status and habitat use (Layman et al. 2007). C:N ratios confirmed that the baleen samples were within the theoretical range for pure keratin in 317 out of 318 samples analysed (O'Connell \& Hedges 1999). Those C: $N$ ratios presented here are the first in the literature for humpback whale baleen and indicate that a value of 3.4 is conservative across taxa for baleen (cf. skin and blubber, Ryan et al. 2012). This provides a useful reference for quality assurance of corresponding $\delta^{15} \mathrm{~N}$ and $\delta^{13} \mathrm{C}$ values for future studies using CF-EA-IRMS.

By only analysing baleen plates comprising $>1 \mathrm{yr}$ of growth, potential variability in stable isotope values arising during migration and annual cycles were captured. As capital breeders, fin, humpback and minke whales are all believed to undergo prolonged migration for reproduction and sometimes show high site fidelity to feeding grounds (Jonsgård 1966, Gill \&
Fairbainrns 1995, Stevick et al. 2006, Whooley et al. 2011). However the timing, routes taken and location of breeding areas are not known for these species in the NEA (Anderwald et al. 2011). The large range of stable carbon and nitrogen isotope values, particularly for fin and humpback whales from Irish/UK waters, indicates that baleen was synthesised from a broad isotopic source (i.e. probably more than one set of baseline isotope compositions). This could occur due to feeding in more than one area (e.g. during migration) or differential metabolic fractionation of $\delta^{13} \mathrm{C}$ and $\delta^{15} \mathrm{~N}$ such as that associated with catabolism (Schwarcz 1991, Hobson et al. 1993, 2004, Gannes et al.1997).

\section{Isotopic niche space}

Using SEA $A_{C}$ in SIBER, 3 distinct isotopic niches among fin, humpback and minke whales were delineated, indicating significant resource partitioning in Ireland/UK where they occur sympatrically (Fig. 2). This is surprising considering observational evidence of shared resources (namely clupeids) in inshore waters. While SEA $A_{c}$ showed distinct isotopic niches, overlap between convex hulls did occur at $\delta^{15} \mathrm{~N}$ values of $\sim 11.5 \%$ ond at $\delta^{13} \mathrm{C}$ of $\sim-17 \%$ indicating that any resource competition that may occur is likely to be shortlived (Fig. 2). The overlapping isotopic niche space shared by Irish/UK and Biscayan fin whales suggests connectivity between whales from these regions. It has been shown that baseline $\delta^{13} \mathrm{C}$ values correlate positively with both latitude (Goericke \& Fry 1994, Hofmann et al. 2000) and proximity to shore (Fry 2006). All else being equal, Irish/UK fin whales would be expected to exhibit more depleted

$\delta^{13} \mathrm{C}$ values compared to their southern counterparts considering that $\delta^{13} \mathrm{C}$ values generally decrease with latitude, particularly at latitudes $>50^{\circ} \mathrm{N}$. The opposite was observed however; thus, latitudinal variations in baseline $\mathrm{C}$ isotopes cannot explain the distinctive isotopic composition of baleen from Ireland/ UK whales. This finding is consistent with an inshore component to their diet, a pattern unique to whales from the Ireland/UK sample.

\section{Isotopic niche area}

Although distinct with respect to isotopic niche space, fin and humpback whales exhibited the same isotopic niche areas, which were significantly larger than that of minke whales (Fig. 2). Assuming that minke whales assimilated nutrients 
from a baseline subject to similar spatiotemporal variation, the smaller isotopic niche area suggests a more stenophagous diet for this species in the study area. This result is potentially surprising considering that in the North Atlantic, minke whales exhibit a generalist diet comprising fishes (Lindstrøm et al. 2002, Macleod et al. 2004, Pierce et al. 2004) and zooplankton (Hobson et al. 2002). Thus, the differences in isotopic niche area may reflect differences in spatial foraging. By comparison with fin and humpback whales, the feeding range for minke whales may be restricted either geographically or in terms of the number of food webs from which nutrients are derived. Fin whales exhibited the broadest range of $\delta^{13} \mathrm{C}$ values suggestive of feeding over latitudinal gradients (during migration) or in more than one food web, i.e. in both pelagic and inshore waters.

To draw ecological inferences, e.g. on trophodynamics, from a comparison of tissue isotopic variability between species or populations, assumptions concerning spatial variability of basal $\delta^{15} \mathrm{~N}$ and $\delta^{13} \mathrm{C}$ values must be made. At present, our understanding of spatial and temporal variability in marine isotopic baselines is incomplete and more baseline isotopic data are required for a robust interpretation of either isotope niche dimensions or geographic assignment using an isoscapes (stable isotope mapping) approach (West et al. 2010, Trueman et al. 2012b). Compound- specific stable isotope analysis can be used to decouple the relative contributions of trophic and baseline variation in stable carbon and nitrogen isotope compositions (Popp et al. 2007). However, currently these techniques are time consuming and relatively costly, prohibiting routine application to large sample suites.

\section{Implications for conservation and management}

Stable isotope values have previously been used as a complementary tool towards resolving population structure (Clegg et al. 2003, Foote et al. 2009, Newsome et al. 2009). Our isotopic niche models indicate that fin whales sampled from Ireland/UK and the Bay of Biscay were spatially explicit from those of the Mediterranean Sea. The isotopic niche area however was different between the 3 groups of fin whales analysed, possibly reflecting either different foraging strategies between fin whales from Ireland/UK and Bay of Biscay or differential variability in isotopic baselines. The IWC recognises a single fin whale management unit ('British Isles-Spain-Portugal') from the sampling regions included in this study (Donovan 1991, IWC 2007).
Our results support the 'British Isles-Spain-Portugal' management unit as ecologically relevant given that considerable overlap in isotopic niche was found in whales from both the Bay of Biscay and Ireland and the UK. Comparing our data with those published by Bentaleb et al. (2011), however, supports the hypothesis that Mediterranean fin whales constitute a distinct population and should be considered as a separate management unit (Bérubé et al. 1998). Interestingly, outliers from the study by Bentaleb et al. (2011) occur within the isotopic niches of both Biscayan and Irish/UK fin whales, supporting the hypothesis that limited exchange does occur between fin whales from the Mediterranean and adjacent waters (Castellote et al. 2012).

Enriched $\delta^{13} \mathrm{C}$ values $>-17 \%$ observed in samples from Ireland and the UK but not the Mediterranean or the Bay of Biscay is surprising in light of the expected depletion in baseline $\delta^{13} \mathrm{C}$ values with latitude. This pattern is therefore consistent with a significant inshore diet component unique to fin whales from Ireland and the UK, where they have been observed feeding on forage fishes close to shore (Whooley et al. 2011). While direct evidence from satellite telemetry demonstrates that exchange between IWC stocks does occur (Mikkelsen et al. 2007), the geographic range of our samples did not allow for discrimination between the 'Faro-West Norway' and 'British Isles-Spain-Portugal' manage- ment units. More research is needed to investigate the range and connectivity of fin whales in the North Atlantic, where population structure remains poorly resolved due to recurrent gene flow between sub- populations (Bérubé et al. 1998, Palsbøll et al. 2004). We propose that stable isotope analysis would complement molecular genetic data towards resolving population structure of fin whales and other rorquals in the North Atlantic (e.g. Clegg et al. 2003).

\section{CONCLUSION}

Carbon and nitrogen isotopic niche partitioning was found for fin, humpback and minke whales occurring sympatrically in Irish/UK waters, although based on a small sample size. This somewhat contradicts recent field observations of fin, humpback and minke whales foraging on common prey in Irish waters. Instead, diet overlap between these species may only be short-term, which shows the importance of considering averaged diet over longer time periods, as afforded by stable isotope analysis of accretionary tissues such as baleen. Until such time as robust 
estimates of diet solutions can be derived, most promisingly using Bayesian mixing models (Parnell et al. 2010), the isotopic niche concept can progress our understanding of poorly studied ecological communities by helping to formulate pertinent hypotheses on resource partitioning, competition and foraging strategies. We have shown that stable isotope analysis has a role to play in identifying connectivity between fin whales inhabiting adjacent regions in the NEA. Bayesian mixing models complemented by satellite telemetry will be required to clarify resource partitioning and nutrient sources at fine taxonomic and spatial scales among those rorquals occurring sympatrically in the NEA. This would further facilitate informed ecosystems-based management decisions towards more effective conservation of marine resources, including rorquals, which are still recovering from centuries of overexploitation.

Acknowledgements. We are grateful to all those who pro- vided baleen samples, making this study possible: A. Aguilar, G. Burrows, N. Davison, L. Hunt, C. MacLeod, A. Malcolm, N. Massett, M. O'Connell, K. and P. O'Dwyer, K. O'Hara, E. Rogan, A. Speer, P. Whooley, J. Wilson and $P$. Wilson. Three anonymous reviewers are gratefully acknowledged for their suggestions which improved the manuscript. Thanks also to M. O'Connell and the membership of the Irish Whale and Dolphin Group for reporting data on stranded whales, which is available in real-time online (www.iwdg.ie).

\section{LITERATURE CITED}

Aguilar A (2008) Fin whale, Balaenoptera physalus. In: Per- rin WF, Würsig B, Thewissen JGM (eds) Encyclopedia of marine mammals. Elsevier-Academic Press, Amsterdam, p 433-437

Anderwald P, Daníelsdóttir AK, Haug T, Larsen F and others (2011) Possible cryptic stock structure for minke whales in the North Atlantic: implications for conservation and management. Biol Conserv 144:2479-2489

Baker CS, Clapham PJ (2004) Modelling the past and future of whales and whaling. Trends Ecol Evol 19:365-371

Ballance L, Pitman RL, Hewitt RP, Siniff DB, Trivelpiece WZ, Clapham PJ, Brownell RL Jr (2006) The removal of large whales from the Southern Ocean: evidence for long-term ecosystem effects. In: Estes JA (ed) Whales, whaling and ocean ecosystems. University of California Press, Berke- ley, CA, p 215-230

Bearhop S, Adams CE, Waldron S, Fuller RA, Macleod H (2004) Determining trophic niche width: a novel approach using stable isotope analysis. J Anim Ecol 73: 1007-1012

Bentaleb I, Martin C, Vrac M, Mate B, Mayzaud P, Siret D, de Stephanis $R$, Guinet C, others (2011) Foraging ecology of Mediterranean fin whales in a changing environment elucidated by satellite tracking and baleen plate stable isotopes. MarEcolProg Ser 438:285-302

Bérubé $M$, Palsbøll $P$ (1996) Identification of sex in cetaceans by multiplexing with three ZFX and ZFY specific primers. Mol Ecol 5:283-287

Bérubé M, Aguilar A, Dendanto D, Larsen F and others (1998) Population genetic structure of North Atlantic, Mediterranean Sea and Sea of Cortez fin whales, Balaenoptera physalus (Linnaeus 1758): analysis of mito- chondrial and nuclear loci. Mol Ecol7:585-599

Castellote M, Clark CW, Lammers MO (2012) Fin whale (Balaenoptera physalus) population identity in the west- ern Mediterranean Sea. Mar Mamm Sci 28:325-344

Clegg SM, Kelly JF, Kimura M, Smith TB (2003) Combining genetic markers and stable isotopes to reveal population connectivity and migration patterns in a Neotropical migrant, Wilson's Warbler (Wilsonia pusilla). Mol Ecol 12: 819-830

DeNiro MJ, Epstein S (1978) Influence of diet on the distribution of carbon isotopes in animals. Geochim Cosmochim Acta 42:495-506

Donovan GP (1991) A review of IWC stock boundaries. Rep Int Whale Comm (special issue) 13:39-68

Fairley JS (1981) Irish whales and whaling. Blackstaff Press, Belfast

Foote AD, Newton J, Piertney SB, Willerslev E, Gilbert MTP (2009) Ecological, morphological and genetic divergence of sympatric North Atlantic killer whale populations. Mol Ecol 18:5207-5217

Fry B (2006) Stable isotope ecology, 3rd edn. Springer, New York, NY

Gannes LZ, O'Brien DM, Del Rio CM (1997) Stable isotopes in animal ecology: assumptions, caveats, and a call for more laboratory experiments. Ecology78:1271-1276

Gerber LR, Morissette L, Kaschner K, Pauly D (2009) Should whales be culled to increase fishery yield? Science 323: 880-881

Gill A, Fairbainrns RS (1995) Photo-identification of the minke whale Balaenoptera acutorostrata off the Isle of Mull, Scotland. Dev Mar Bio 4:129-132

Goericke R, Fry B (1994) Variations of marine plankton $\delta^{13} \mathrm{C}$ with latitude, temperature, and dissolved $\mathrm{CO}_{2}$ in the world ocean. Global Biogeochem Cycles 8:85-90

Graham BS, Koch PL, Newsome SD, McMahon KW, Auri- oles D (2010) Using isoscapes to trace the movements and foraging behavior of top predators in oceanic ecosystems. In: West JB, Bowen GJ, Dawson TE, Tu KP (eds) Isoscapes: understanding movement, pattern, and pro- cess on Earth through isotope mapping. Springer, New York, NY, p 299-318

Harrod C, Grey J, McCarthy TK, Morrissey M (2005) Stable isotope analyses provide new insights into ecological plasticity in a mixohaline population of European eel. Oecologia 144:673-683

Hobson KA, Alisauskas RT, Clark RG (1993) Stable-nitrogen isotope enrichment in avian tissues due to fasting and nutritional stress: implications for isotopic analyses of diet. Condor 95:388-394

Hobson KA, Fisk A, Karnovsky N, Holst M, Gagnon JM, Fortier M (2002) A stable isotope $\left(\delta^{13} \mathrm{C}, \delta^{15} \mathrm{~N}\right)$ model for the North Water food web: implications for evaluating trophodynamics and the flow of energy and contaminants.Deep-SeaRes II49:5131-5150

Hobson KA, Riget F, Outridge P, Dietz R, Born E (2004) Baleen as a biomonitor of mercury content and dietary history of North Atlantic minke whales (Balaenopetra acutorostrata): combining elemental and stable isotope approaches. Sci Total Environ 331:69-82

Hofmann M, Wolf-Gladrow DA, Takahashi T, Sutherland SC, Six KD, Maier-Reimer E (2000) Stable carbon isotope distribution of particulate organic matter in the ocean: a model study. Mar Chem 72:131-150

Hutchinson GE (1957) A treatise on limnology: geography, physics, and chemistry. Geography and physics of lakes. Wiley, New York, NY

International Whaling Commission (IWC) (2007) Report of the Subcommittee on the revised management procedure.J Cetacean Res Manag 9:88-128 
Jackson AL, Inger R, Parnell AC, Bearhop S (2011) Comparing isotopic niche widths among and within communities: SIBER-stable isotope Bayesian ellipses in R. J Anim Ecol 80:595-602

Jackson MC, Donohue I, Jackson AL, Britton JR, Harper DM, Grey J (2012) Population-level metrics of trophic structure based on stable isotopes and their application to invasion ecology. PLoS ONE 7:e31757

Jennings S, Warr KJ (2003) Environmental correlates of large-scale spatial variation in the $\delta^{15} \mathrm{~N}$ of marine ani- mals. Mar Biol 142:1131-1140

Jonsgård A (1966) The distribution of Balaenopteridae in the North Atlantic Ocean. In: Norris KS (ed) Whales, dol- phins and porpoises. University of California Press, Berkley/Los Angeles, CA, p 114-123

Laidre KL, Heide-Jørgensen MP, Heagerty P, Cossio A, Bergström B, Simon M (2010) Spatial associations between large baleen whales and their prey in West Greenland. Mar Ecol Prog Ser 402:269-284

Layman CA, Arrington DA, Montaña CG, Post DM (2007) Can stable isotope ratios provide for community-wide measures of trophic structure? Ecology88:42-48

Lindstrøm U, Haug T, Røttingen I (2002) Predation on her- ring, Clupea harengus, by minke whales, Balaenoptera acutorostrata, in the Barents Sea. ICES J Mar Sci 59:58-70

MacKenzie KM, Palmer MR, Moore A, Ibbotson AT, Beau- mont WR, Poulter DJ, Trueman CN (2011) Locations of marine animals revealed by carbon isotopes. Sci Rep 1:21

Macleod K, Fairbairns R, Gill A, Fairbairns B, Gordon J, Blair-Myers C, Parsons EC (2004) Seasonal distribution of minke whales Balaenoptera acutorostrata in relation to physiography and prey off the Isle of Mull, Scotland. MarEcolProg Ser 277:263-274

Mendes S, Newton J, Reid RJ, Zuur AF, Pierce GJ (2007) Stable carbon and nitrogen isotope ratio profiling of sperm whale teeth reveals ontogenetic movements and trophic ecology. Oecologia 151:605-615

Mikkelsen B, Bloch D, Heide-Jorgensen MP (2007) A note on movements of two fin whales (Balaenoptera physalus) tracked by satellite telemetry from the Faroe Islands in 2001. J Cetacean Res Manag 9:115-120

Mitani Y, Bando T, Takai N, Sakamoto W (2006) Patterns of stable carbon and nitrogen isotopes in the baleen of com- mon minke whale Balaenoptera acutorostrata from the western North Pacific. Fisheries Sci72:69-76

Montoya JP (2007) Natural abundance of ${ }^{15} \mathrm{~N}$ in marine planktonic ecosystems. In: Michener RH, Lajtha K (eds) Stable isotopes in ecology and environmental science. Wiley-Blackwell, New York, NY, p 176-201

Newsome S, Etnier M, Kurle C, Waldbauer J, Chamberlain C, Koch P (2007a) Historic decline in primary productivity in western Gulf of Alaska and eastern Bering Sea: iso- topic analysis of northern fur seal teeth. Mar Ecol Prog Ser 332:211-224

Newsome SD, Martinez del Rio C, Bearhop S, Phillips DL (2007b) A niche for isotopic ecology. Front Ecol Environ 5:429-436

Newsome SD, Etnier MA, Monson DH, Fogel ML (2009) Ret- rospective characterization of ontogenetic shifts in killer whale diets via $\delta 13 \mathrm{C}$ and $\delta 15 \mathrm{~N}$ analysis of teeth. Mar Ecol Prog Ser 374:229-242

Newsome SD, Clementz MT, Koch PL (2010) Using stable isotope biogeochemistry to study marine mammal ecology. Mar Mamm Sci 26:509-572

O'Brien J, Berrow SD, McGrath D, Evans PGH (2009) Cetaceans in Irish waters: a review of recent research. Biol Environ Proc R Ir Acad B 109:63-88

O'Connell TC, Hedges RE (1999) Investigations into the effect of diet on modern human hair isotopic values. Am J Phys Anthropol 108:409-425

Palsbøll PJ, Bérubé M, Aguilar A, Notarbartolo-Di-Sciara G, Nielsen R (2004) Discerning between recurrent gene flow and recent divergence under a finite-site mutation model applied to North Atlantic and Mediterranean Sea fin whale (Balaenoptera physalus) populations. Evolution 58:670-675
Parnell AC, Inger R, Bearhop S, Jackson AL (2010) Source partitioning using stable isotopes: coping with too much variation. PLoS ONE 5:e9672

Pauly D, Christensen V, Guénette S, Pitcher TJ and others (2002) Towards sustainability in world fisheries. Nature 418:689-695

Piatt JF, Methven DA (1992) Threshold foraging behavior of baleen whales. Mar Ecol Prog Ser 84:205-210

Pierce G, Santos M, Reid R, Patterson I, Ross H (2004) Diet of minke whales Balaenoptera acutorostrata in Scottish (UK) waters with notes on strandings of this species in Scotland 1992-2002. J Mar Biol Assoc UK84:1241-1244

Pierce GJ, Santos MB, Cervino S (2007) Assessing sources of variation underlying estimates of cetacean diet composition: a simulation study on analysis of harbour porpoise diet in Scottish (UK) waters. J Mar Biol Assoc UK 87: 213-221

Popp BN, Graham BS, Olson RJ, Hannides C and others (2007) Insight into the trophic ecology of yellowfin tuna, Thunnus albacares, from compound-specific nitrogen isotope analysis of proteinaceous amino acids. Terr Ecol 1:173-190

Ramos R, González-Solís J (2012) Trace me if you can: the use of intrinsic biogeochemical markers in marine top predators. Front Ecol Environ 10:258-266

Rau GH, Takahashi T, Des Marais DJ (1992) The relation- ship between $\delta^{13} \mathrm{C}$ of organic matter and $\left[\mathrm{CO}_{2}(\mathrm{aq})\right]$ in ocean surface water: data from JGOFS site in the north- east Atlantic Ocean and models. Geochim Cosmochim Acta 56:1413-1419

R Development Core Team (2011) R: a language and envi- ronmentfor statistical computing. Vienna

Relini G, Orsi Relini L, Cima C, Fasciana C and others (1992) Macroplancton, Meganyctiphanes norvegica, and fin whales, Balaenoptera physalus, along some transects in the Ligurian Sea. Eur ResCetacean 6:134-137

Roman J, Palumbi SR (2003) Whales before whaling in the North Atlantic.Science 301:508-510

Ryan C, McHugh B, Trueman CN, Harrod C, Berrow SD, O'Connor I (2012) Accounting for the effects of lipids in stable isotope $\left(\delta^{13} \mathrm{C}\right.$ and $\delta^{15} \mathrm{~N}$ ) analysis of skin and blubber of balaenopterid whales. Rapid Commun Mass Spec- trom 26:2745-2754

Schell D, Saupe S, Haubenstock N (1989a) Natural isotope abundances in bowhead whales (Balaena mysticetus) baleen: markers of aging and habitat use. Ecol Stud 68:260-269

Schell DM, Saupe SM, Haubenstock N (1989b) Bowhead whale (Balaena mysticetus) growth and feeding as esti mated by $13 \mathrm{C}$ techniques. Mar Biol 103:433-443

Schwarcz HP (1991) Some theoretical aspects of isotope paleodiet studies. J Archaeol Sci 18:261-275

Skern-Mauritzen M, Johannesen E, Bjørge A, Øien N (2011) Baleen whale distributions and prey associations in the Barents Sea. Mar Ecol Prog Ser 426:289-301

Sonnerup RE, Quay PD, McNichol AP, Bullister JL, Westby TA, Anderson HL (1999) Reconstructing the oceanic $13 \mathrm{C}$ Suess effect. Global Biogeochem Cycles 13:857-872

Springer AM, Estes J, Van Vliet G, Williams T and others (2003) Sequential megafaunal collapse in the North Pacific Ocean: an ongoing legacy of industrial whaling? Proc Natl Acad Sci USA 100:12223-12228

Stevick PT, Allen J, Clapham PJ, Katona SK, and others (2006) Population spatial structuring on the feeding grounds in North Atlantic humpback whales (Megaptera novaeangliae). J Zool (Lond) 270:244-255

Sumich J (2001) Growth of baleen of a rehabilitating gray whale calf. Aquat Mamm 27:234-238

Tagliabue A, Bopp L (2008) Towards understanding global variability in ocean carbon-13. Global Biogeochem Cycles 22: GB1025, doi:10.1029/2007GB003037

Trites AW, Christensen V, Pauly D (2006) Effects of fisheries on ecosystems: Just another top predator? In: Boyd IL, Wanless S, Camphuysen CJ (eds) Atlantic top predators in marine ecosystems. Cambridge University Press, Cambridge, p 11-27 
Trueman CN, MacKenzie KM, Palmer MR (2012a) Stable isotopes reveal linkages between ocean climate, plank-

ton community dynamics, and survival of two populations of Atlantic salmon(Salmo salar). ICES J Mar Sci 69: 784-794

Trueman CN, MacKenzie KM, Palmer MR (2012b) Identifying migrations in marine fishes through stable-isotope analysis. J Fish Biol 81:826-847

Visser F, Hartman KL, Pierce GJ, Valavanis VD, Huisman J (2011) Timing of migratory baleen whales at the Azores in relation to the North Atlantic spring bloom. Mar Ecol Prog Ser 440:267-279

Wall D, O'kelly I, Whooley P, Tyndall P (2009) New records of blue whales (Balaenoptera musculus) with evidence of possible feeding behaviour from the continental shelf slopes to the west of Ireland. Mar Biodiversity Rec 2:e128

West JB, Bowen GJ, Dawson TE (2010) Isoscapes: under-standing movement, pattern, and process on earth through isotope mapping, 1st edn. Springer, New York, NY

Whooley P, Berrow S, Barnes C (2011) Photo-identification of fin whales (Balaenoptera physalus L.) off the south coast of Ireland. Mar Biodivers Rec 4(e8) 